\title{
Hinterland and foreland structures of the eastern Maghreb Tell and Atlas thrust belts: tectonic controlling factors, pending questions, and oil/gas exploration potential of the Pre-Triassic traps
}

\author{
Sami Khomsi $i^{1,2}$. François Roure ${ }^{3}$.Jaume Vergés ${ }^{4}$ \\ Published online: 4 March 2022 \\ C) Saudi Society for Geosciences 2022
}

Keywords Tell $\cdot$ Atlas $\cdot$ Structural transects $\cdot$ Folds and thrusts $\cdot$ Tectonic events $\cdot$ Numidian $\cdot$ Triassic salt $\cdot$ Oil/gas traps

\section{Presentation of the special issue Geology of North Africa and Mediterranean regions}

This special issue of the AJGS entitled Geology of North Africa and Mediterranean regions is a follow-up of the AGIC (Atlas Georesources International conferences) organized in 2017 by the Georesources Laboratory and CERTE, Tunis, University of Carthage. This event was a major occasion for geoscientists from Arabian, Maghrebian, and European countries to present their recent findings and research results in the characterization of different georesources in North Africa, the Mediterranean, and surrounding areas, thus also including the Arabian plate.

This thematic issue is composed of 33 papers covering a wide spectrum of topics and fields, from architecture and thermicity of sedimentary basins to structural evolution, oil/ gas exploration, fractured reservoirs, water resources, aquifer characterization, and applied geophysics.

This article is part of the Topical Collection on Geology of North Africa and Mediterranean regions

Sami Khomsi

samykhomsi@yahoo.ca

1 Department of Geoexploration, Faculty of Earth Sciences, King Abdulaziz University, Jeddah, Saudi Arabia

2 Laboratoire Géoressources (LGR), CERTE, Université of Carthage, Tunisia

3 IFP Énergies Nouvelles, Ruel Malmaison, France

4 Group of Dynamics of the Lithosphere (GDL), Geosciences Barcelona (GEO3BCN-CSIC), Barcelona, Spain

\section{Architecture and thermicity of sedimentary basins, structural evolution, and oil/gas exploration}

This special issue contains 13 papers covering different sedimentary basins in North Africa, Yemen, Egypt, and Greece, with a special attention on the oil and gas potential in the Tell and the Atlas belts and their respective foreland basins, and a particular interest in the salt mobility and petroleum traps characterization, including papers by Bédir et al., Khelil et al., Khomsi et al., Arfaoui et al., Khouni et al., Tari et al., Naji et al., Boughalmi et al., El Sawy et al., Mezni et al., Tseloras et al., and Bagazi et al.

In this thematic, the authors used different approaches involving structural analysis, seismic data interpretations, balanced cross-sections, modeling of source rocks maturity and petroleum systems, and a description of trap occurrences.

\section{Fractured reservoirs}

This thematic comprises 8 papers covering different basins in North Africa, from the Atlas fold-and-thrust belt, the eastern foreland basins and northern Sahara platform, and the western province of Saudi Arabia, including investigations of deep subsurface reservoirs by seismic analysis, applied sequence and seismic stratigraphy techniques, well logging interpretations, and structural analysis at different scales. This thematic is covered by papers presented by Souei et al., Bédir et al., Lachaal et al., Nefzi et al., Hammami et al., Saleem et al., Thebti et al., and Al Ghamdi.

\section{Applied geophysics}

A set of 4 papers was presented, dealing with applied geophysics with their use in structural characterization, water 


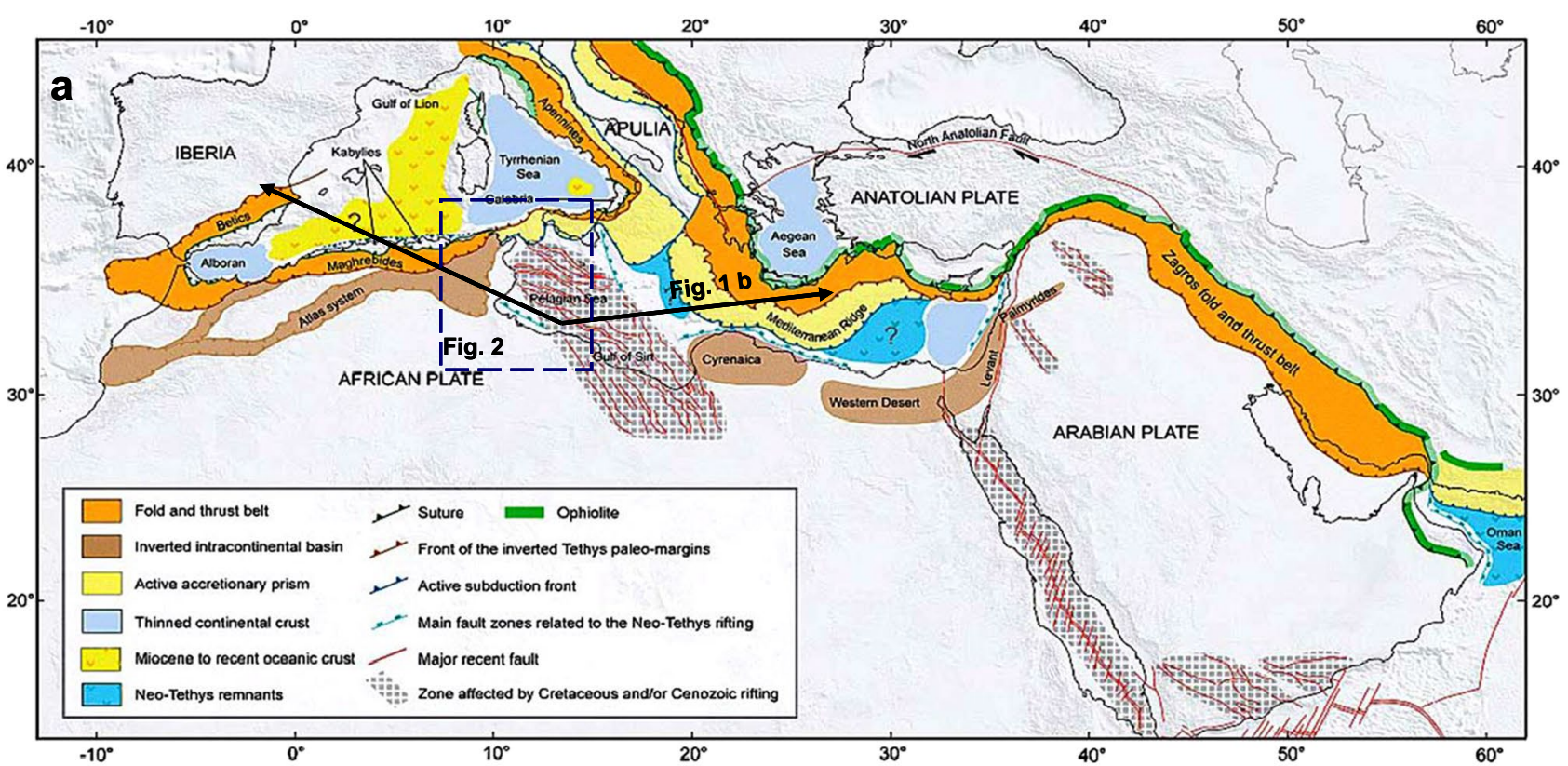

b
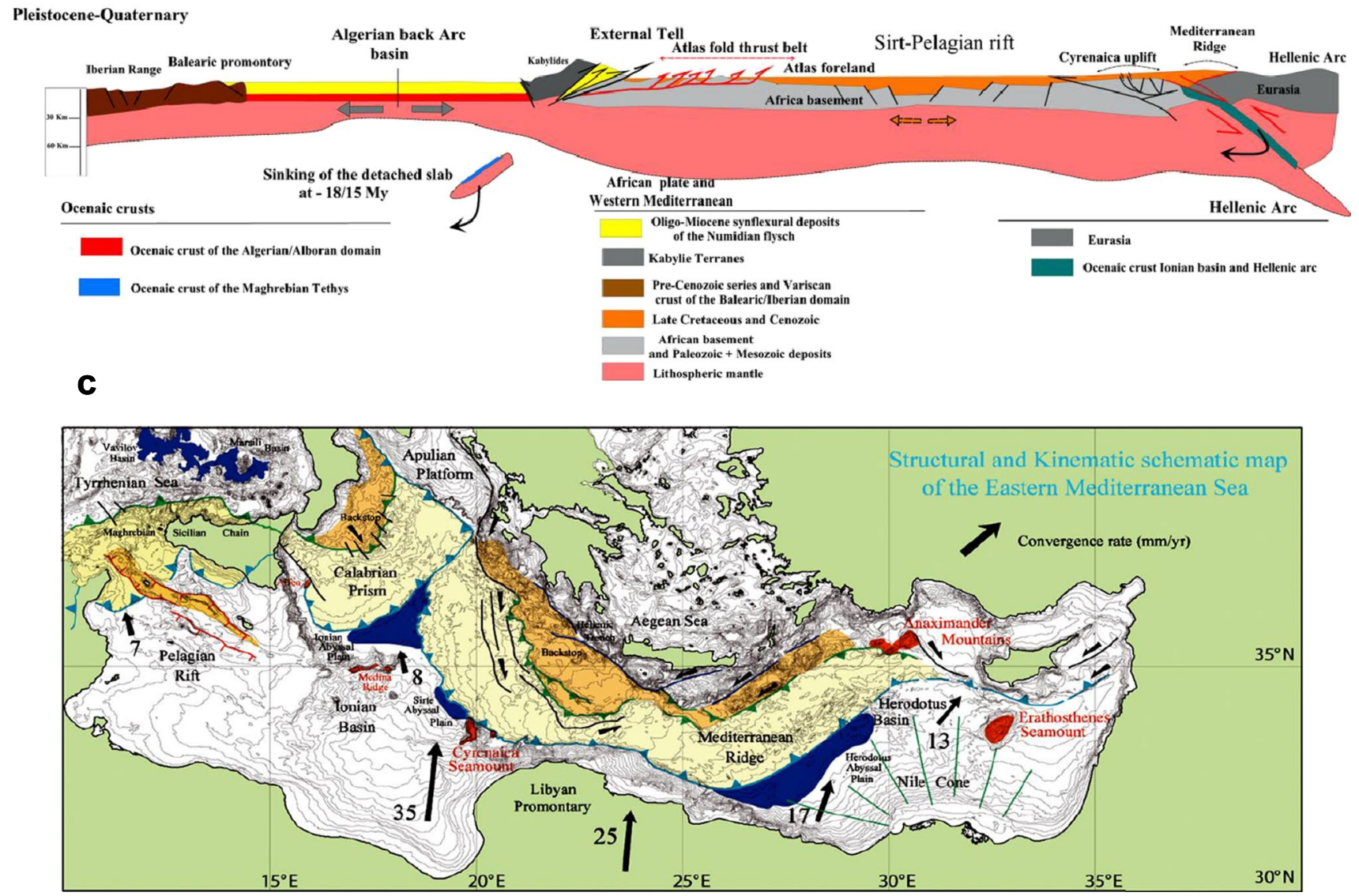

resources, and subsurface investigations of georesources. Different techniques were presented involving gravity interpretation and modeling, electromagnetic modeling, wire-logging techniques interpretations and $3 \mathrm{D}$ models. The papers of this thematic were presented by: Mouakhar et al., Al Garni., Azeiz et al., and Lamouchi et al. 
४Fig. 1 The Maghrebides fold-and-thrust belt within the CircumMediterranean Alpine system issued from the collisional tectonics of the Tethyan margins. a From Frizon de Lamotte et al. (2011). b Kinematic and paleo-tectonic transect in the western Mediterranean during Pleistocene-Quaternary after the slab sinking beneath the Algerian back-arc basin. Notice that the subduction of the northeastern African margin beneath the South Eurasian plate from Cyrenaica to Egypt still continues. c Actual movements of the eastern Mediterranean basin structures with rates of convergence in $\mathrm{mm} /$ year measured by satellite and GPS equipment (Dotmed Project, 2005; ChamotRooke et al. 2005a, b). Notice that in the Sirt offshore and Cyrenaica, high ranges of convergence are now observed (35 mm/year) compared to the Maghreb in Tunisia where the value attains $7 \mathrm{~mm} /$ year. The map indicates also continuing Africa/Eurasia convergence after slab sinking in the western Mediterranean Maghrebian basins in the Langhian

\section{Water resources and aquifers characterization}

This topic was covered by a set of 8 papers dealing with different aspects of water resources studies in Northern Africa and Arabia, two regions suffering problems of water resources and their impact on regional aridity. The papers present a wide range of approaches involving: geostatistics, environment impacts, re-use of treated waters, pollution, and vulnerability of water resources, rainfall variations, and climate change tendencies. The papers were presented by Chargui et al., Subyani et al., Khaddar et al., Moussa et al., Saleem et al., Lachaal et al., Bedir et al., and ben Hammouda.

\section{Northern Africa Tell and Atlas fold and thrust belts in their geodynamic context}

As a whole, the Tell fold-and-thrust belt corresponds to a tectonic wedge (Fig. 1) built from a long and complex evolution at the North African margin of Maghrebian sedimentary basins (Frizon de Lamotte et al., 2000 and 2009; Granath and Casero, 2004; Roure et al., 2012; Khomsi et al., 2016 and 2018; Arab et al., 2020). Several tectonic pulses were recorded over the Cenozoic times, during the NW-dipping subduction of the Ligurian-Tethys ocean segment, linked to the North African margin, underneath the European margin (Roure et al., 1990 and 2019; Jolivet et al., 1999; Vergés and Sàbat, 1999; Hippolyte et al., 1994; Roca et al., 2004; Finetti et al., 2005; Guerrera, 2014; Guerrera et al. 2019).The subsequent SE-directed roll back of this subduction during the Oligocene-Langhian caused the retreat of the Tethys slab, the formation of the Algerian Basin behind, and the collision of the AlKaPeCa domain against the deep margin of the north Atlassic Basin in the Langhian (Roca et al., 2004; Roure et al., 2012;
Van Hinsbergen et al., 2014). Soon after the continental collision, a mantle delamination process followed by slab break-off occurred in post-Langhian times (Roure et al., 2012; Van Hinsbergen et al., 2014) (Fig. 1). The present position of the sinking slabs beneath the Algerian and Tunisian Tell-Atlas systems has been confirmed by seismic tomography by Fichtner and Villaseñor (2015). These major geodynamic events were accompanied by vertical, up and down lithospheric movements controlling the thermal maturity of the organic matter in the different sedimentary basins during their Neogene-Quaternary evolution with flexing during the tectonic loading phase of the Oligocene-Langhian and later unflexing after slab break-off and coeval uplift and erosion (Fig. 1). These lithospheric movements have amplitudes of hundreds of meters and have controlled the thermal as well as subsidence history and source rocks maturity of the basins and preservation/ migration of oil and gas in traps and reservoirs. A recent study of the lithospheric structure of the Tunisian margin determined that the combined processes of delamination and slab break-off could affect a region with a wavelength of $100 \mathrm{~km}$ reaching dynamic topographies of $\geq 500 \mathrm{~m}$ (Kumar et al., 2021).

But the knowledge of their impact on the thermal maturities of the basins is still limited in the Maghreb, and the Tell and future researches should treat specific questions on the thermal maturity of source rocks and their links with the vertical movements of the lithosphere (Roure, 2008 and 2014).

The Tell fold-and-thrust belt of the Eastern Maghrebides constitutes an important mobile segment of the Alpine collisional chains (Fig. 1) issued from the accretion of the ALKAPECA (Alboran-Kabylides-Peloritan-Calabria) domain along the southern margin of the Maghrebian Tethys during post-Langhian times. The collision wedge underwent compressional tectonics with the individualization of internal and external zones (Roca et al., 2004; Roure et al., 2012): the internal zones correspond chiefly to the Kabylides Paleozoic terranes thrusted on the Eocene-Oligocene deep-water flexural basins. The external zones correspond to the Eastern Tell of Algeria and Tunisia, characterized by imbricate thrust fan systems thrusting on top of the intracontinental and inverted sedimentary basins of the Northern Atlas to the south.

North of the Kabylides and tectonic suture, the hinterland was impacted by the opening of the Algerian back arc basin (Fig. 1) during the Upper Oligocene-Miocene until now, recording more than $2000 \mathrm{~m}$ of sediments over the extended continental to oceanic substratum of the Algerian Basin (Roure et al., 2012): a recent compilation is recently presented in Bellucci et al. (2021). 

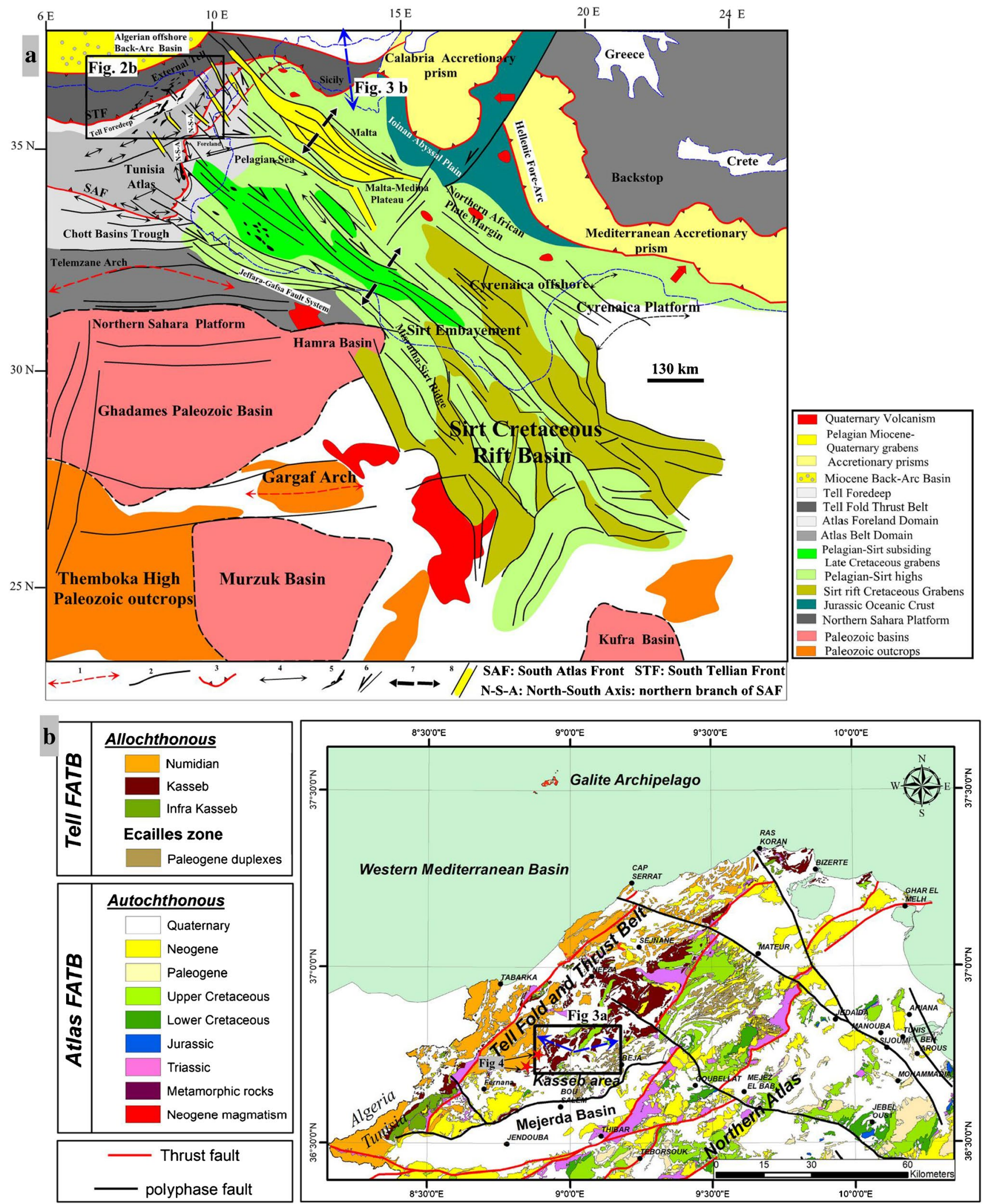

Fig. 2 Tectonic map of the eastern Maghreb major structures (a) and geologic map of the eastern Tell in Tunisia (b) together with the positions of Transects $3 \mathrm{a}$ in Kasseb and transect 3 b. For 1 a, captions:
Captions. 1: major arch, 2: major fault, 3: major thrust, 4: major anticline, 5: salt bodies, 6: major strike-slip fault, 7: grabens 


\section{Tectonic accretion during the Late Eocene inversion events in the Tell and the Atlas: the nature and significance of the major Oligocene unconformity}

After the pioneer works and monographies (Vila; 1980; Rouvier, 1985; Raoult, 1974; Raoult et al., 1982), numerous papers published during the last two decades provide a better overview and constraints on the tectonic pulses versus structural styles (Figs. 23456 to 7) in the thrust wedge of the Eastern Maghreb (Bracène and Frizon de Lamotte, 2002; Benaouali-Mebarek et al. 2006; Masrouhi et al., 2008; Khomsi et al. 2009a, b and 2019a; Roure et al., 2012; Khelil et al., 2019a, b; 2019b and 2021; Leprêtre et al., 2018; Riahi et al., 2010; Belyaouni et al., 2013). These works agree with thrust tectonics expressed by duplex anticline structures detached above Triassic evaporites and both Cretaceous and Tertiary shale levels as decollement levels separating different structural styles (Fig. 3).

On the other hand, the Atlas belt, at the south-eastern edge of the Tell (Figs. 1 and 5), corresponds chiefly to an inverted intracontinental rift system, issued from positive uplift movements, firstly during the late Eocene and

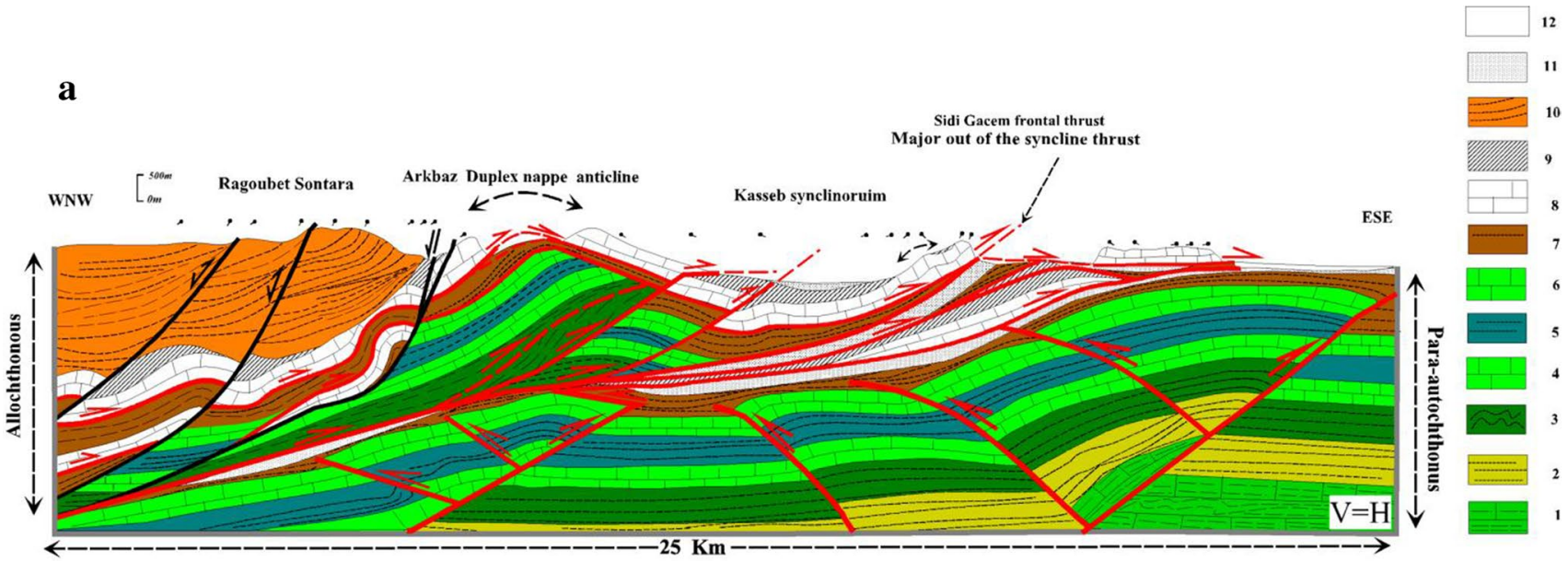

$\geqslant$ : thrust fault, $\sqrt{ }$ : normal to reverse reactivated fault, $\sqrt{ }:$ normal fault, $\bullet:$ Dip of strata,

b

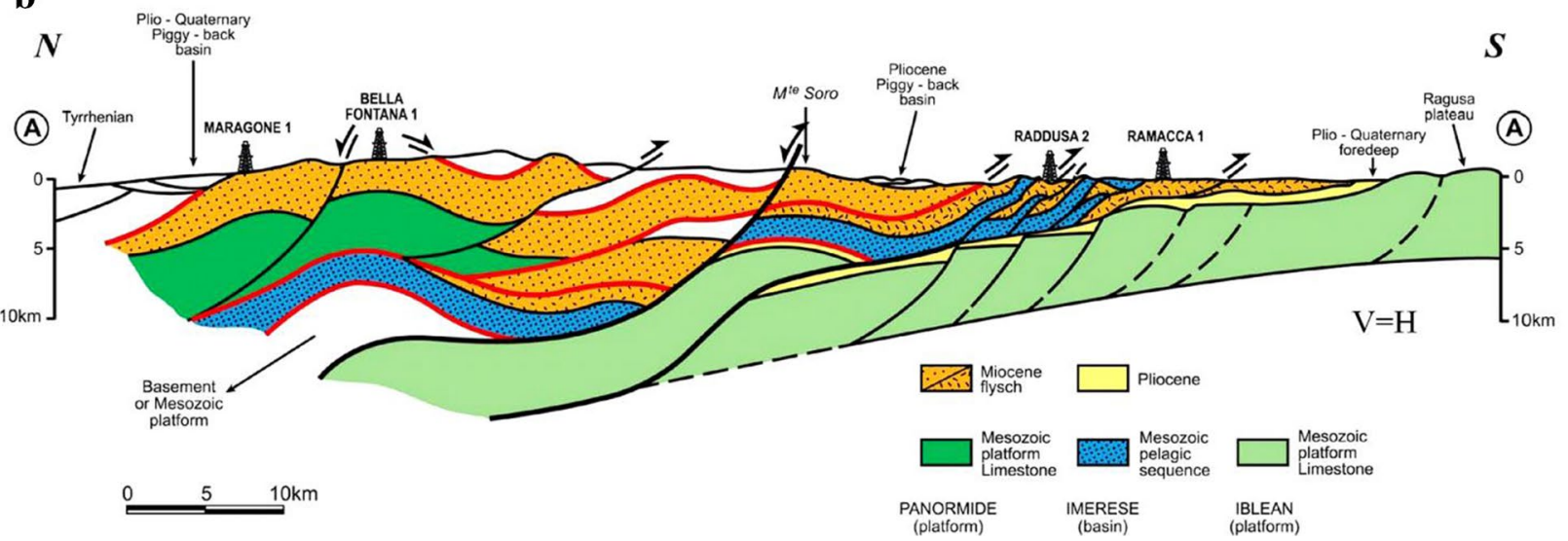

Fig. 3 Structural transects along the Tunisian Tell (a from Khomsi et al., 2021) and the Sicily arc (b from Roure et al., 2012). The two transects show some similarities concerning the Numidian Flysch transported basin over the Maghrebides wedge in a piggy back configuration. The transects underline also the existence of some normal faults and collapse of the inner parts of the belt. They underline also the duplexing of the Mesozoic series underneath the thrust wedge. Notice that the allochthonous system of the Tunisian Tell overhangs Langhian flexural series, whereas in the Sicilide, the allochthon over- hangs the Upper Miocene-Quaternary foredeep series. Notice that both in Sicily and Tunisia, the Numidian series lye unconformably on duplicated Cretaceous-Cenozoic thrust structures. a 1-Upper Albian, 2-Cenomanian-Turonian, 3-Coniacian-Santonian, 4Upper Santonian-Lower Campanian, 5-Upper Campanian-Lower Maastrichtian, 6-Upper Maastrichtian, 7-Paleocene, 8-Ypresian basinal limestones (Kasseb units), 9-Late Eocene shales, 10Numidian Flysch, 11-Oligocene to Aquitanian-Langhian, 12Upper Miocene-Quaternary 
subsequently during the Upper Miocene-Quaternary Alpine movements (Frizon de Lamotte et al., 2000 and 2009; Khomsi et al. 2009a, b; Belyaouni et al., 2013; Roure et al., 2012; Bahrouni et al., 2020; Khelil et al., 2020). The late Eocene compressional events are well recorded in the Tell and in the Atlas belt, as well as in its southern and eastern foreland basins (Fig. 5). These events represent the onset of shortening affecting the whole North African Tethyan margin with the climax of the subduction of the North African margin underneath the South European margin. It is well expressed by a regional and wide angular unconformity at the base of the Oligocene-Miocene synflexural series (Figs. 34 to 5) of the Numidian flysch deposits in the Tell and the marine to continental Fortuna Formation in the Atlas. The angular unconformity at the base Oligocene expresses the onset of the tectonic accretion in the moving thrust wedge of the Tell since the late Eocene. This tectonic accretion of the Cretaceous-Eocene basinal series was strong enough to control the erosion and reworking of pre-Oligocene series deposited in deep canyons. In fact, detailed structural analyses of the basal contact of the Oligo-Miocene Numidian Flysch outline a sedimentary contact between the lower Numidian beds, with a downlap to lateral onlapping on underlying Ypresian Kasseb units as well as erosion of the late Eocene series (Figs. 3 and 4) together with some synchronous tectonics affecting the Oligo-Miocene beds (Figs. 3 and 4). In the Kasseb locality (Fig. 3), which is a key area to understand the structural contacts of the Numidian Flysch and the underlying Kasseb units, the Numidian is sealing unconformably Eocene
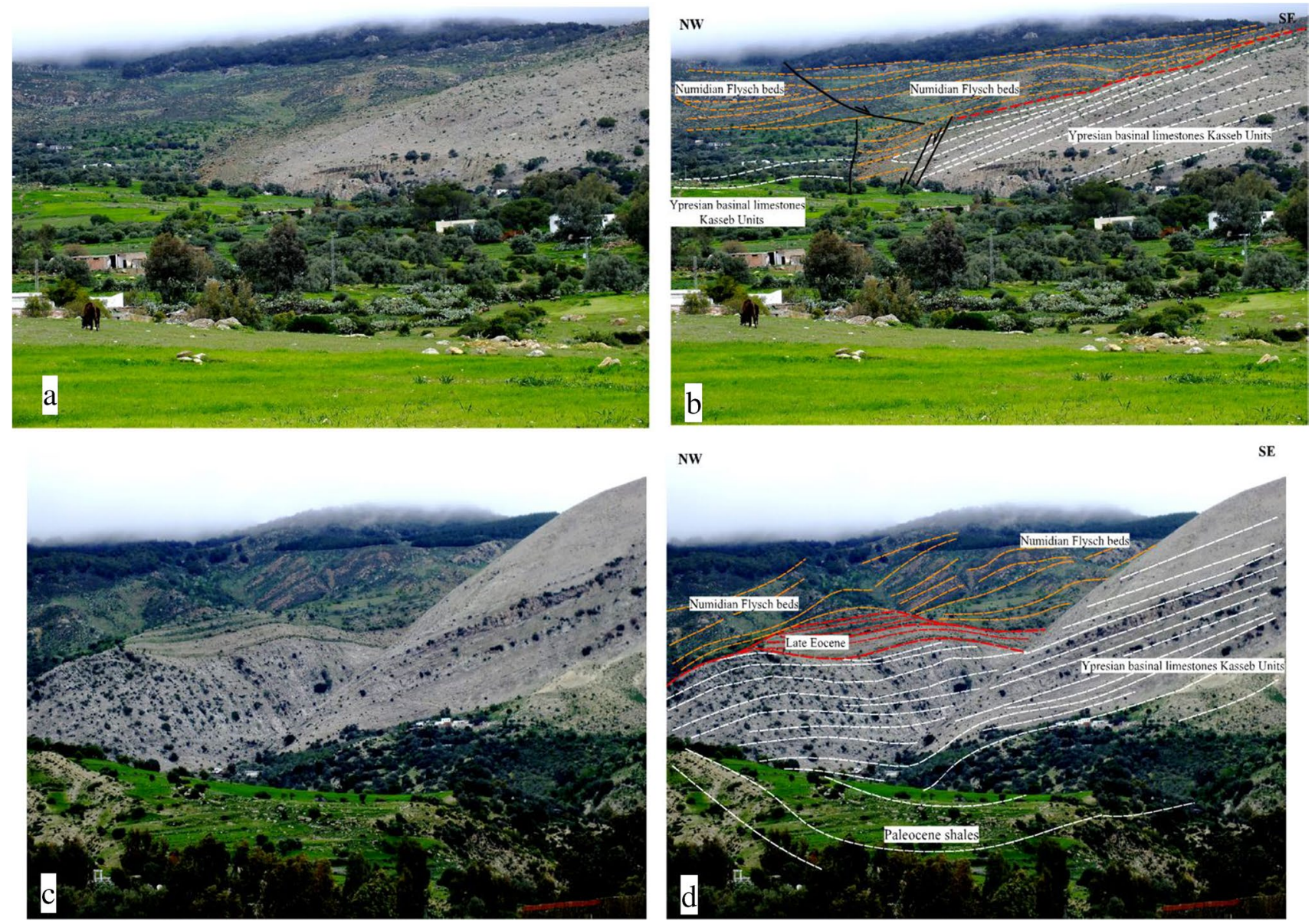

Fig. 4 Panoramic pictures in Kasseb area looking north (position on Fig. 2b) and corresponding interpretations underlining a regional and enhanced unconformity separating the Numidian Oligo-Miocene flexural series above eroded Ypresian Kasseb limestone allochthonous series. The angular unconformity is materialized by erosion of some Eocene sequences with a lateral onlapping and sealing of extensional structures at the base of the Numidian Flysch $(\mathbf{a}, \mathbf{b})$. The panorama sketches $\mathbf{c}$ and $\mathbf{d}$ underline donwlapping and draping of the Numidian lower beds over late Eocene shales and Ypresian limestones, with important erosion of the Late Eocene beds laterally together with filling of paleo-valleys by the Numidian. Notice that these features underline an important flexural and basinal unconformable megasequence over the Kasseb accreted units 
duplex structures. All these features agree with the fact that the late Eocene uplift events related to the Atlas Eocene compressions were strong enough to initiate the tectonic accretion and stacking of the Kasseb units and Cretaceous carbonates series of the foreland (Fig. 3).

\section{Some important pending questions: significance of the Triassic salt as a regional seal for subsurface structures}

Despite our increasing knowledge on the structural styles (Figs. 6 and 7) and tectonic events in the Maghrebides and the Atlas, some important structural questions arise concerning specifically on the along-strike variations of this structural style, the importance of the Triassic salt (Perthuisot and Rouvier, 1992; Vila et al., 1999a, b; Khomsi et al. 2009a, 2018; Masrouhi et al., 2013; Troudi et al., 2017; Soto et al., 2017; Khelil et al., 2019a, b a, b and 2020) in the control of the overall tectonic grain (Fig. 6), the structural configuration of the deep seated structures underneath the Triassic evaporite (Soto et al., 2017; Khomsi et al., 2019a, b), and the nature of the PreTriassic series/structures, which remain mostly unknown. All these questions influence not only our knowledge of the deep architecture of the Tell FABT but also the exploration of the oil and gas habitats in these important regional structures in Algeria and Tunisia, both in the Atlas and its foreland basin as well.

In fact, it is questionable whether or not the Paleozoic sequences are involved in the Alpine rejuvenation
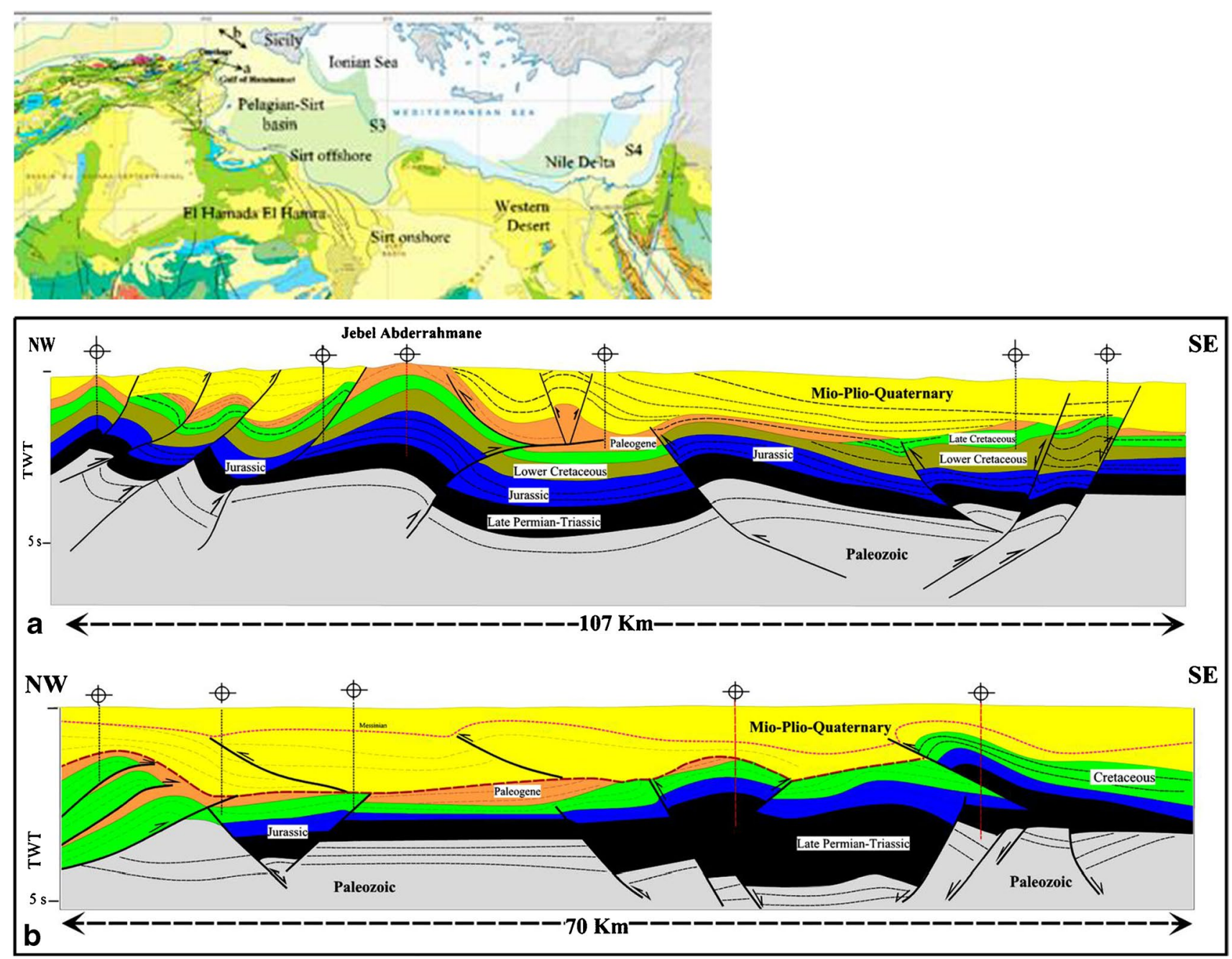

Fig. 5 Two structural transects in the Gulf of Hammamet and Sicily Channel underlining inverted Mesozoic structures in the subsurface of the foreland domain. These transects outline two major tectonic pulses materialized by two major angular/erosional unconformities: The late Eocene and the late Miocene-Quaternary Alpine compres- sions produced the rejuvenation and positive inversions of former extensional basins. Notice that the transects show also Paleozoic structures buried beneath the Mesozoic megasequence. From Casero and Roure (1994) modified by Khomsi et al. (2016). Position map above from the Geologic map of Africa (2016) 


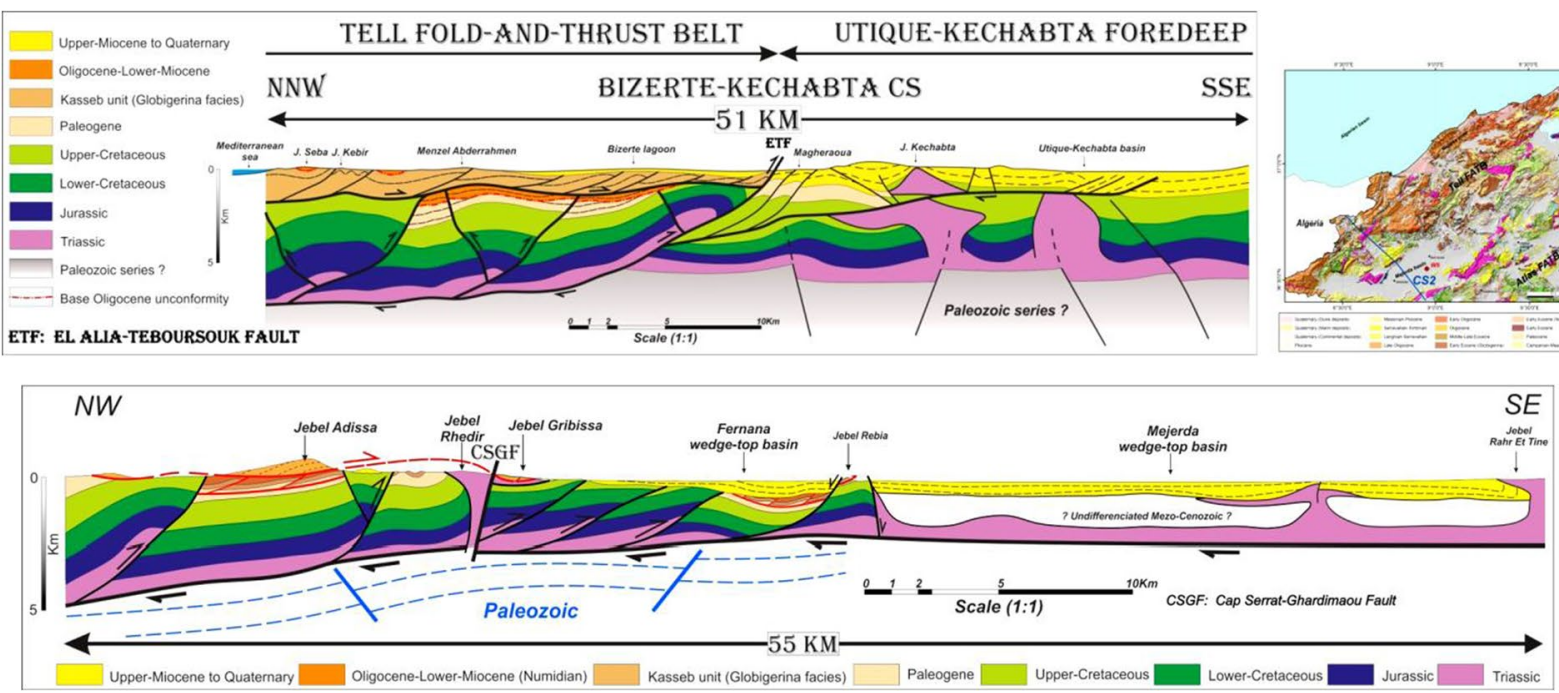

Fig. 6 Structural transects in the Tell of Tunisia (from Khelil et al., 2020 and Khomsi et al., 2021). The first transect (labeled CS1 on the position map) shows very important Triassic salt movements materialized by diapiric structures as salt wall and salt plugs thrusted over the Upper Miocene-Quaternary Utique Kechabta foredeep basin. The transect also displays major thrusting and ongoing compressions and rejuvenation of the Tell wedge and its foreland basin and Northern
Atlas structures. The second transect (labeled CS2 on the position map) cross-cuts the inner parts of the Tell wedge from Fernana to the Northern Atlas belt at the south-eastern edge crossing the collapsed Mejerda Basin at the front of the Tell. The transect underlines large amounts of vertical Triassic salt motion with diapirs and salt plugs in the inner Tell as well as in the Northern Atlas of the Tell system. In fact, the Triassic salt regional seal still preludes the unlocking of petroleum exploration in the Paleozoic structures underneath the Meso-Cenozoic subsurface structures of the Tell in Algeria and Tunisia as well. Some recent published transects and cross-sections argue for the existence of possible active petroleum systems and gas traps seated in the Paleozoic (Khomsi et al., 2019a, b a and 2021).

\section{Future oil and gas exploration}

The Mesozoic-Cenozoic petroleum potential in the Tell of Tunisia was discussed in some papers and regional works during the last years (El Euchi et al., 2004; Mejri et al., 2006; Khomsi et al., 2018, 2019a, b and 2021). These studies account for the occurrence of potential oil/gas traps, especially in the northern offshore of Tunisia where the Meso-Cenozoic system is seemingly very interesting and potentially very prolific (Khomsi et al., 2019a, b and 2021).

However, deep seismic records of good resolutions with a dense and sufficient grid are still lacking in the Tell of Tunisia despite the fact that few old 2D seismic campaigns have been somehow re-processed. Meanwhile, the resolution is still insufficient and far beyond what would be expected to unlock the exploration of potential oil/gas plays in the offshore of the Tell.
In addition, the thick Triassic salt and regional seal, which is characterized by its chaotic seismic facies, does not allow to properly image potential traps within the Mesozoic sequences and is also a limiting factor to clearly identifying deeper oil and gas traps in the Paleozoic structures (Roure et al., 2019; Khomsi et al., 2019a, b).

The structural transects presented in the preceding sessions (Figs. 3, 5, 6, and 7) underline the likely occurrence of Paleozoic petroleum structures, but again, the scarcity and limited qualities of seismic profiles still preclude the unlocking of the Paleozoic system too.

\section{Conclusion: on the need of deep seismic sections in the Tell and Atlas}

In addition to the Mesozoic-Cenozoic composite petroleum systems of North Africa, assumed to be very prolific and potentially interesting even if not yet discovered, the deep structures in the offshore of the Tell deforming the Paleozoic system beneath the Atlas and Tell belts and their respective forelands basins remain mostly unknown. These Paleozoic systems could be as prolific as those in Algeria and Libya and southern Tunisia, as suggested in the previously discussed cross-sections.

Therefore, we urgently need to identify the potential subsurface Paleozoic structures and traps seated beneath the 


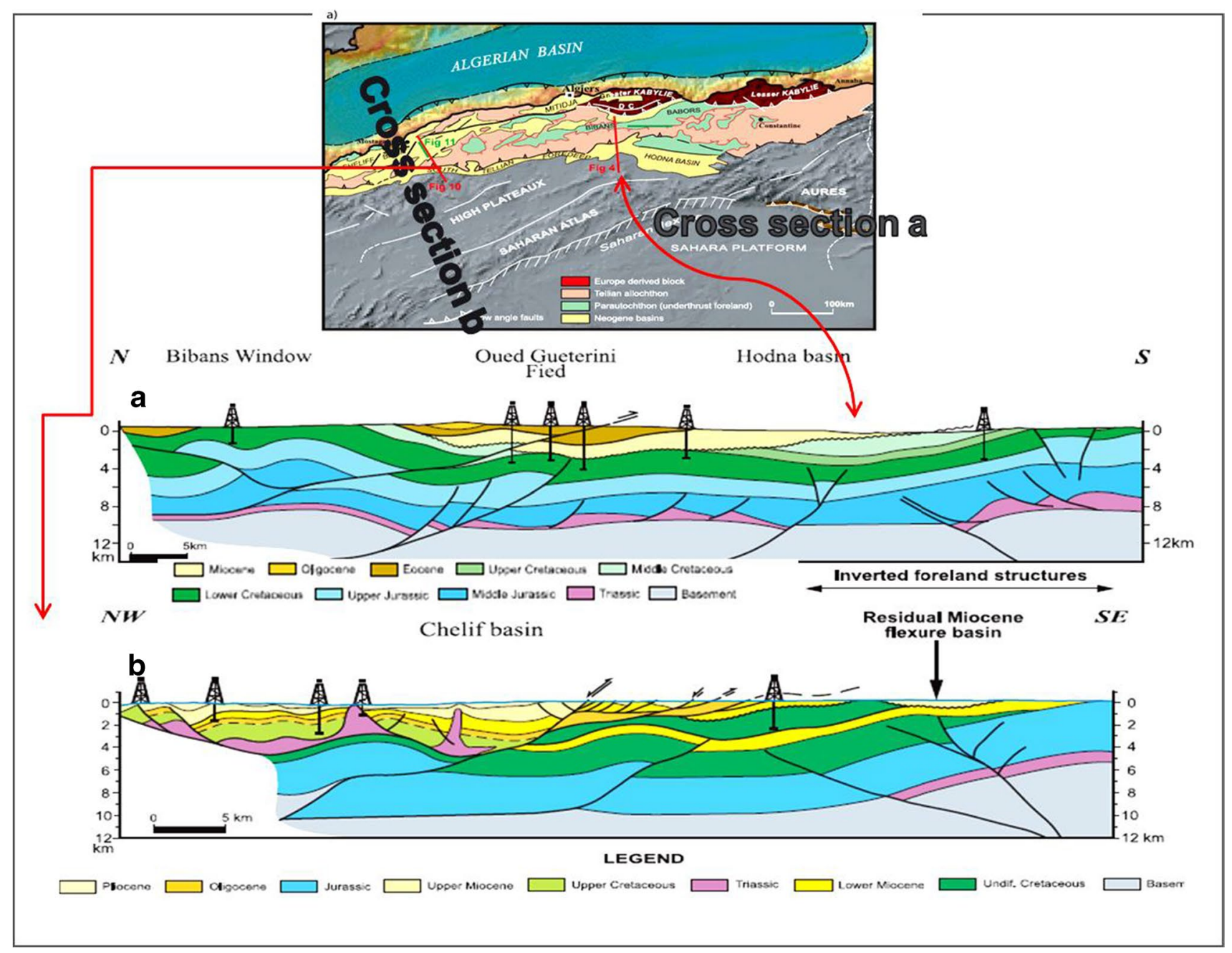

Fig. 7 Structural transects in the Tell of Algeria (from Roure et al., 2012). The transect above (labeled a on the position map) shows buried Tethyan rifted system affecting the Jurassic and Cretaceous series, materialized by tilted blocks and half-grabens. This transect crosses the Oued Gueterini oil field sourced from Cenomanian-Turonian Bahloul source rocks. The Miocene foreland sequences lye unconformably on Upper Cretaceous successions in the same way as the Langhian deposits of the Tell of Tunisia. In Oued Guetrini field, the Eocene sedimentary series are duplicated and are thrusted on the

Atlas and Tell, likely to be sealed by the regional Triassic salt level. To unravel these structures, we do need a deep seismic imaging project along the North African Maghrebian margin with sufficient recording depth (i.e., down to 10 to $15 \mathrm{~s}$ TWT) to visualize properly the potential preTriassic salt hydrocarbon plays. We hope that in the future, a research consortium involving exploration companies, universities, research centers, and groups from both sides of the Mediterranean Sea will be able to organize and operate such deep seismic imaging project and open new oil and gas perspectives.
Miocene flexural basin as in the Kasseb area (Fig. 3). The Chelif transect underlines the transported Chelif basin over the Miocene flexural basin in a piggy-back configuration. Notice the lateral tectonic transport of salt plugs intruding the Cretaceous sequences, which have been transported SE-ward together with the entire Chelif piggy-back basin on top of its Atlassic foreland basin. Notice also the duplication of the Miocene sequences lying SE on the Cretaceous series. This transect crossing Algeria shows many similarities with the transect of Fig. 6 in the Utique-Kechabta basin in Tunisia

Acknowledgements We wish to thank all reviewers and colleagues from different countries (France, Spain, Austria, Tunisia, Egypt, Greece, and Saudi Arabia), universities and companies for their corrections and useful scientific comments they provided to the authors.

\section{References}

Arab M, Maherssi C, Granjeon D, Roure F, Déverchère J, Cuilhé L, Hassaim M, Mouchot N, Doublet S, Khomsi S (2020) On the origin and consequences of crustal-scale extension between Africa and Sicily since Late Miocene: insights from the Kaboudia area, 
western Pelagian Sea. Tectonophysics. https://doi.org/10.1016/j. tecto.2020.228565

Bahrouni N, Masson F, Meghraoui M, Saleh M, Maamri R, Dhaha F, Arfaoui M (2020) Active tectonics and GPS data analysis of the Maghrebian thrust belt and Africa-Eurasia plate convergence in Tunisia. Tectonophysics 785:228440. https://doi.org/10.1016/j. tecto.2020.228440

Belayouni H, Guerrera F, Martin M (2013) Paleogeographic and geodynamic Miocene evolution of the Tunisian Tell (Numidian and post-Numidian successions ), bearing with the Maghrebian Chain. Inter J Earth Scinces 102:831-855. https://doi.org/10.1007/ s00531-012-0824-x

Bellucci M, Aslanian D, Moulin M, Rabineau M, Leroux E, Pellen R, Poort J, Del Ben A, Gorini C, Camerlenghi A (2021) Salt morphologies and crustal segmentation relationship: new insights from the Western Mediterranean Sea. Earth-Science Rev 222:103818. https://doi.org/10.1016/j.earscirev.2021.103818

Benaouali-Mebarek N, Frizon de Lamotte D, Roca E, Bracène R, Faure R, Sassi JLW, Roure F (2006) Post-Cretaceous kinematics of the Atlas and Tell systems in central Algeria: early foreland folding and subduction-related deformation. CR Geosciences, Thematic Issue: Some Recent Developments on the Geodynamics of the Maghreb 338:41-49

Bracène R, Frizon de Lamotte D (2002) The origin of intraplate deformation in the Atlas system of western and central Algeria: from Jurassic rifting to Cenozoic-Quaternary inversion. Tectonophysics 357:207-226

Casero P, Roure F (1994) Neogene deformations at the Sicilian-North African plate boundary. Peri-Tethyan Platforms. Editions Technip, Paris, 1994, 27-50

Chamot-Rooke N, Rabaute C, Kreemer A (2005a) A western Mediterranean ridge mud belt correlates with active shear strain at the prism-backstop geological contact (2005) Geological Society of America. Geology 33(11):861-864. https://doi.org/10.1130/ G21469.1

Chamot-Rooke N, Rangin C, Le Pichon X, Rabaute A (2005b) DOTMED Working Group. DoTMed Cd Rom project (2005b) Deep offshore tectonics of the Eastern Mediterranean : a synthesis of deep marine data in the Eastern Mediterranean : the Ionian basin and margins, the Calabria wedge and the Mediterranean ridge. Mémoires de la Société géologique de France, nouv. série., mémoire no 177

DOTMED Working Group. DoTMed Cd Rom project (2005) Deep offshore tectonics of the Eastern Mediterranean : a synthesis of deep marine data in the Eastern Mediterranean : the Ionian basin and margins, the Calabria wedge and the Mediterranean ridge. Mémoires de la Société géologique de France, nouv. série., mémoire no 177

El Euchi H, Saidi M, Fourati L, El Marhessi C (2004) Northern Tunisia thrust belt : deformation models and hydrocarbon systems. Swennen r, Roure F and Granath J w, Eds, Deformation, Fluid Flow and Reservoir Appraisal in Foreland Fold-and-Thrust Belts: AAPG Hedberg Series 1:371-380

Fichtner A, Villaseñor A (2015) Crust and upper mantle of the western Mediterranean - constraints from full-waveform inversion, Earth Planet. Sci Lett 428:52-62. https://doi.org/10.1016/j.eps1.2015. 07.038

Finetti F, Lentini S, Carbone A, Del Ben A, Di Stefano E, Forlin P, Garnier M, Pipa A, Prizzon A (2005) Geological outline of Sicily and lithospheric tectono-dynamics of its Tyrrhenian margin from new CROP seismic data. CROP Project: deep seismic exploration of the central Mediterranean and Italy, pp 319-375

Frizon de Lamotte D, Saint-Bézard B, Bracène R (2000) The two main steps of the Atlas building and geodynamics of the western Mediterranean. Tectonics 19(4):740-761

Frizon de Lamotte D, Leturmy P, Missenard Y, Khomsi S, Ruiz G, Saddiqi O, Guillocheau F, Michard A (2009) Mesozoic and Cenozoic vertical movements in the Atlas system (Algeria, Morocco, Tunisia): an overview. Tectonophysics 475:9-28. https://doi.org/10. 1016/j.tecto.2008.10.024

Frizon de Lamotte D, Raulin C, Mouchot N, Wrobel Daveau JC, Blanpied C, Ringenbach JC (2011) The southernmost margin of the Tethys realm during the and Cenozoic: initial geometry and timing of the inversion processes. 2011. Tectonics 30, TC3002. https:// doi.org/10.1029/2010TC002691.

Geologic map of Africa (2016) Scale 1: 10000000 35th world geological congress, 2016, Cape Town South Africa UNESCO/BRGM/ CCGM/CGMW

Granath JW and P Casero (2004) Tectonic setting of the petroleum systems of Sicily, in R. Swennen, F. Roure, and J. W. Granath, eds., Deformation, fluid flow, and reservoir appraisal in foreland fold and thrust belts: AAPG Hedberg Series, 1 391-411

Guerrera F (2014) Martín-Martín M (2014) Geodynamic events reconstructed in the Betic, Maghrebian, and Apennine chains (centralwestern Tethys). Bull Soc Geol Fr 185:329-341

Guerrera F, Martin-Martín M, Tramontana, (2019) Evolutionary geological models of the central-western peri-Mediterranean chains: a review. Int Geol Rev. https://doi.org/10.1080/00206814.2019. 1706056

Hippolyte J, C, Angelier J, Roure F, and Casero P, (1994) Piggyback basin development and thrust belt evolution: Structural and paleostress analyses of Plio-Quaternary basins in the Southern Apennines. J Struct Geol 16:159-173. https://doi.org/10.1016/01918141(94)90102-3

Jolivet L, Frizon de Lamotte D, Mascle A, Séranne M (1999) The Mediterranen basins: tertiary extension within the Alpine Orogen-An introduction. Geol. Soc London, Special Publication 156:1-14. https://doi.org/10.1144/GSL.SP.1999.156.01.02

Khelil M, Souloumiac P, Maillot B, Khomsi S, Frizon de Lamotte D (2019a) How to build an extensional basin in a contractional setting? Numerical and physical modelling applied to the Mejerda Basin at the front of the eastern Tell of Tunisia. Jour Struc Geol 129:103887. https://doi.org/10.1016/j.jsg.2019.103887

Khelil M, Souloumiac P, Frizon de Lamotte D, Khomsi S, Maillot B, Gaidi S, Bédir M, Zargouni F (2019b) Is the Mejerda Wedge-Top Basin of Northern Tunisia a consequence of basal friction change? A theoretical and experimental approach. In: Rossetti F. et al. (eds) The Structural Geology Contribution to the Africa-Eurasia Geology: Basement and Reservoir Structure, Ore Mineralisation and Tectonic Modelling. CAJG 2018. Advances in Science, Technology \& Innovation (IEREK Interdisciplinary Series for Sustainable Development). Springer, Cham. 247-249. https://doi.org/10. 1007/978-3-030-01455-1_53

Khelil M, Khomsi S, Frizon de Lamotte D, Souloumiac P, Maillot B (2020) Reply to comment on "how to build an extensional basin in a contractional setting? Numerical and physical modeling applied to the Mejerda basin at the front of the eastern Tell of Tunisia."J Struc Geol 103936. doi:https://doi.org/10.1016/j.jsg.2019.103936

Khelil M, Khomsi S, Roure F, Arfaoui MS, Echihi O, Zargouni F (2021) Late Miocene-Quaternary thrusting in the Utique-Kechabta foreland basin of the Tell, northern Tunisia. Arabian J Geosci 14.doi:https://doi.org/10.1007/s12517-020-06388-2

Khomsi S, Ghazi M, Jemia B, Frizon D, Lamotte D, Maherssi C, Echihi O, Mezni R (2009a). An overview of the Late Cretaceous - Eocene positive inversions and Oligo-Miocene subsidence events in the foreland of the Tunisian Atlas : Structural style and implications for the tectonic agenda of the Maghrebian Atlas system. Tectonophysics 475:38-58. https://doi.org/10.1016/j. tecto.2009.02.027

Khomsi S, Soussi M, Mahersi C, Fakfakh-Ben Jemia H, Riahi S, Bou Khalfa K (2009b) New insights on the structural style of the subsurface of the Tell units in north-western Tunisia issued from seismic imaging: geodynamic implications. CR 
Geoscience 341:347-356. https://doi.org/10.1016/j.crte.2009. 01.002

Khomsi S, Frizon de Lamotte D, Bédir M, Echihi O (2016) The Late Eocene and Late Miocene fronts of the Atlas Belt in eastern Maghreb: integration in the geodynamic evolution of the Mediterranean Domain. Arab J Geosci 9:650-670. https://doi.org/10. 1007/s12517-016-2609-1

Khomsi S, Roure F, Khelil M, Frizon de Lamotte D, Zargouni, F (2018) Thrust belt systems of Northern Africa petroleum implications. Field trip guide, CAJG 2018: 1st Conference of the Arabian Journal of Geosciences (Nov 12 - Nov 15, 2018). 109 pp

Khomsi S, Roure F, Khelil M, Mezni R, Echihi O (2019a) A review of the crustal architecture and related pre-salt oil/gas objectives of the eastern Maghreb Atlas and Tell: need for deep seismic reflection profiling. Tectonophysics 766:232-248. https://doi.org/10. 1016/j.tecto.2019.06.009

Khomsi S, Roure F, Brahim NB, Maherssi C, Arab M, Khelil M (2019b) Structural styles, petroleum habitat and traps in the Pelagian-Sirt Basins, Northern Africa: an overview and future exploration developments. In: Rossetti F. et al. (eds) The Structural Geology Contribution to the Africa-Eurasia Geology: Basement and Reservoir Structure, Ore Mineralization and Tectonic Modelling. CAJG 2018. Advances in Science, Technology \& Innovation (IEREK Interdisciplinary Series for Sustainable Development). Springer, Cham. doi:https://doi.org/10.1007/978-3-030-01455$1 \_33$

Khomsi S, Khelil M, Roure F, Zargouni F (2021). Surface and subsurface architecture of the Kasseb structures: implications for petroleum exploration beneath the Tellian allochthon, the easternmost portion of the Maghrebides. Arab J Geosci 14.doi:https://doi.org/ 10.1007/s12517-020-06401-8

Kumar, A., M. Fernàndez, J. Vergés, M. Torne, and I. Jiménez-Munt (2021), Opposite symmetry in the lithospheric structure of the Alboran and Algerian basins and their margins (Western Mediterranean): Geodynamic Implications, J. Geophys. Res. Solid Earth, 126(7), doi:https://doi.org/10.1029/2020JB021388

Leprêtre R, Frizon de Lamotte D, Combier V, Vives G, Mohn O, Eschard R (2018b) The Tell-Rif orogenic system (Morocco, Algeria, Tunisia) and the structural heritage of the southern Tethys margin. Bull. Soc. Géol. France 189, 10 doi:1051/bsgf/2018009

Masrouhi A, Ghanmi M, Slama MMB, Youssef MB, Vila JM, Zargouni $F(2008)$ New tectono-sedimentary evidence constraining the timing of the positive tectonic inversion and the Eocene Atlasic phase in northern Tunisia: Implication for the North African paleo-margin evolution. C r Geoscience 340:771-778. https://doi.org/10. 1016/j.crte.2008.07.007

Masrouhi A, Bellier O, Koyi H, Vila JM, Ghanmi M (2013) The evolution of the Lansarine-Baouala salt canopy in the North African Cretaceous passive margin in Tunisia. Geol Mag 150:835-861. https://doi.org/10.1017/S0016756812000763

Mejri F, Burollet PF, Ben Ferjani A (2006) Petroleum geology of Tunisia. A renewed synthetis. ETAP Memoir, 22, $233 \mathrm{pp}$

Perthuisot V, Rouvier H (1992) Les diapirs du Maghreb central et oriental : des appareils variés, résultats d'une évolution structurale et pétrogénétique complexe. Bull Soc Géol France 163(6):751-760

Raoult JF (1974) Géologie du centre de la chaîne numidique (Nord du Constantinois, Algérie), Soc. Géol. France, L III, Mém. 121, pp 1-163. Pl I à IX

Raoult JF, Renard M, Melieres F (1982) Le flysch Maurétanian de Guerrouch: cadre structural, données sédimentologiques et géochimiques (Petite Kabylie, Algérie). Bull. Soc. Géol. France (7). XXIV 3:611-626

Riahi S, Soussi M, Boukhalfa K, Ben Ismail-Lattrache K, Stow D, Khomsi S, Bedir M (2010) Stratigraphy, sedimentology, and structure of the Numidian flysch thrust belt in northern Tunisia. Jour. African Earth Sci; 57, 109-126. doi:https://doi.org/10. 1016/j.jafrearsci.2009.07.016

Roca E, Frizon de Lamotte D, Mauffret A, Bracène R, Verges J, Benaouali N, Fernandez M, Munoz JA, Zeyen H (2004) Transmedtranscect II [Aquitaine basin, Pyrenees, Ebro basin, Catalan coastal ranges, Valancia trough, Balearic promontory, Algerian basin, Tell, Sahara Atlas, Sahara platform. In: Cavazza W, et al. (eds). The Transmed Atlas -the Mediterranean region from Crust to Mantle. Springer, Berlin Heildelberg

Roure F (2014) Crustal architecture, thermal evolution and energy resources of compressional basins. Geol Belg 17(2):182-194

Roure F (2008) Foreland and Hinterland basins: what controls their evolution? Swiss J. Geosci. Birkhäuser Verlag, Basel, pp 1-25. doi https://doi.org/10.1007/s00015-008-1285-x8

Roure F, Howell DG, Muller C, Moretti I (1990) Late Cenozoic subduction complex of Sicily. J Struct Geology 12(2):259-266

Roure F, Casero P \& Addoum B (2012) Alpine inversion of the North African margin and delamination of its continental lithosphere, Tectonics, 31, TC3006, doi:https://doi.org/10.1029/2011TC0029 89

Roure F, Khomsi S, de Lamotte DF. Leprêtre R (2019) Tethyan and Alpine controls on the crustal architecture of the Tunisian and Algerian Atlas and Tell: needs for coupled deep seismic soundings and tomography. In: Rossetti F. et al. (eds) The Structural Geology Contribution to the Africa-Eurasia Geology: Basement and Reservoir Structure, Ore Mineralisation and Tectonic Modelling. CAJG 2018. Advances in Science, Technology \& Innovation (IEREK Interdisciplinary Series for Sustainable Development). Springer, Cham. doi:https://doi.org/10.1007/978-3-030-01455-1_3

Rouvier H (1985) Géologie de l'extrême-nord tunisien: tectonique et paléogéographies superposées à l'extrémité orientale de la chaîne nord-maghrébine. PhD Thesis, Ann. Min. Géol., Tunis, p 427

Soto JI, Flinch JF, Tari G (2017) Permo-Triassic basins and tectonics in Europe, North Africa and the Atlantic Margins. In: Soto JI, Flinch JF, Tari G (Eds) Permo-Triassic salt provinces of Europe, North Africa and the Atlantic margins: tectonics and hydrocarbon potential, Elsevier Edition, 3-41, doi:https://doi.org/10.1016/ b978-0-12-809417-4.00038-0

Troudi H, Tari G, Alouani W, Cantarella G, (2017) Styles of salt tectonics in central Tunisia: an overview, Permo-Triassic salt Provinces of Europe, North Africa and the Atlantic margins: Tectonics and hydrocarbon potential. doi:https://doi.org/10.1016/B978-0-12809417-4.00026-4

Van Hinsbergen DJJ, Vissers RLM, Spakman W (2014) Origin and consequences of western Mediterranean subduction, rollback, and slab segmentation. Tectonics 33:393-419. https://doi.org/10. $1002 /$ tect. 20125

Vergés J, Sàbat F (1999) Constrains on the Neogene Mediterranean kinematic evolution along and $1000 \mathrm{~km}$ transect from Iberia to Africa. Geol. Soc. London 156:63-80. https://doi.org/10.1144/ GSL.SP.1999.156.01.05

Vila JM (1980) La chaîne alpine d'Algérie orientale et des confins algéro-tunisiens. PhD thesis, Université Pierre-et-Marie-Curie (Paris), p 665

Vila JM, Kassaa S, Bouhlel S, Ben Youssef M, Dali T, Ghanmi M (1999) Inversion tectonique de structures halocinétiques et localisation des minéralisations ( $\mathrm{Zn}, \mathrm{Sr}$ ); émergence au Jebel Bou Khil (nord-ouest tunisien) d'un chevauchement entre un domaine nord a "glaciers de sel" sous-marins et un domaine sud a "diapirs typique. Bull Soc Géol France 170:161-172 